\title{
COMPARISON OF MEAT COMPOSITION AND SENSORY VALUES OF TWO DIFFERENT STRAINS OF BROILER CHICKENS
}

\author{
COMPARACIÓN DE LA COMPOSICIÓN DE LA CARNE Y VALORES SENSORIALES EN \\ DOS LÍNEAS DE POLLOS PARA CARNE
}

\author{
Sogunle, O.M. ${ }^{1 A *}$, Egbeyale, L.T. ${ }^{1 A}$, Alajo, O.A. ${ }^{1 A}$, Adeleye, O.O. ${ }^{1 A}$, Fafiolu, A.O. ${ }^{1 B}$, \\ Onunkwor, O.B. ${ }^{1 C}$, Adegbite, J.A. ${ }^{1 A}$ and Fanimo, A.O. ${ }^{1 A}$ \\ ${ }^{1}$ University of Agriculture. Abeokuta. Ogun State. Nigeria. ${ }^{A}$ Department of Animal Production and Health. \\ BDepartment of Animal Nutrition. 'Department of Biochemistry. *jidesogunle@yahoo.com
}

\section{AdDitionAL KEYWORDS}

Breast. Thigh.

\section{SUMMARY}

This study was designed to compare chemical composition and quality of carcass parts of 99 broiler chickens of Arbor acre and Marshal MY strains, respectively at the Teaching and Research Farm, University of Agriculture, Abeokuta, Nigeria. At the $56^{\text {th }}$ day of the experiment, 6 birds per replicate were slaughtered after euthanization for carcass analysis and evaluation. The meat samples from the breast and thigh muscles were analyzed for proximate composition. The data obtained were subjected to a t-test at $5 \%$ significant level. The results on the proximate composition $(p<0.05)$ of the muscles showed that values obtained for the thigh gross energy $(2.11 \mathrm{kcal} / \mathrm{g})$, thigh dry matter $(28.73 \%)$, thigh fibre diameter $(5.24 \mathrm{~mm})$, thigh fat $(8.08 \%)$, breast dry matter $(29.88 \%)$ and breast fibre diameter $(5.54 \mathrm{~mm})$ were higher in Marshal MY strain. Hence, it was concluded that meat quality is a function of genotype and environmental factors.

\section{RESUMEN}

Este studio fue diseñado para comparar la composición química y calidad de las piezas de la canal de 99 broilers de las líneas Arbor Acre y Marshal MY respectivamente, en la Teaching and Research Farm, University of Agriculture, Abeokuta, Nigeria. En el día 56 del experimento, 6 aves por tratamiento fueron sacrificadas humanitariamente para el análisis y evaluación de la canal. Las muestras de carne de los músculos de la pechuga y muslos fueron analizadas para

Recibido: 29-9-08. Aceptado: 22-10-08.

\section{Palabras clave adicionales}

Pechuga. Muslo.

determinar la composición proximal. Los datos obtenidos fueron sometidos a la prueba $\mathrm{t}$, a nivel de $5 \%$ de significación. Los resultados de la composición proximal $(p<0,05)$ de los músculos mostraron que los valores obtenidos para la energía bruta $(2,11 \mathrm{kcal} / \mathrm{g})$, materia seca $(28,73 \%)$, diámetro de las fibras $(5,24 \mathrm{~mm})$ y grasa $(8,08 \%)$ de los muslos y la materia seca $(29,88 \%)$ y diámetro de las fibras $(5,54 \mathrm{~mm})$ de las pechugas fueron mayores en la línea Marshal MY. Se concluye que la calidad de la carne, es función de factores genotípicos y ambientales.

\section{INTRODUCTION}

Poultry meat production has been very dynamic over the last decade and now occupies the second place in the world just after pork (Le Bihan-Duval, 2005). In recent years, interest has increased in the quality attributes of food (Farmer et al., 1997). At the same time, the marketing of poultry has been greatly diversified and as a consequence, selection for edible meat yield, mainly breast yield, has intensified at least for standard production.

There are many factors affecting carcass composition and meat quality of broilers. Carcass composition of broiler has been studied extensively and factors affecting composition include diet, age, sex and 
genotype. Much information is available regarding perimortem and postmortem environmental factors that have a significant impact on these important quality attributes in poultry (Ali et al., 1999). In contrast, little is known about the influence of strains on poultry meat quality. In recent years, interest has increased in the quality attributes of food especially meat products. Hence, this experiment was designed to compare the qualities and sensory values of carcass parts (breast and thigh) of two strains of broiler chickens.

\section{MATERIALSAND METHODS}

The study was conducted at the poultry unit of the Teaching and Research Farm, University of Agriculture, Abeokuta $\left(7^{\circ} 15^{\prime} \mathrm{N}\right.$, $3^{\circ} 25^{\prime} \mathrm{E}$ ) from March to April, 2008. A total of 198 day-old broiler chicks of Arbor acre and Marshal MY strains (99 birds per strain) were obtained from reputable hatcheries in Abeokuta, Ogun State and Ibadan, Oyo State both in Nigeria. The birds were replicated thrice at 33 birds per replicate. The birds were raised on deep litter with dry wood shavings as litter material and fed on the diets shown in table $\mathbf{I}$. At the $56^{\text {th }}$ day of the experiment, six birds from each replicate were randomly selected and slaughtered after euthanization for carcass analysis and evaluation. Meat samples were taken from breast and thigh muscles (skin and bones remaining intact) to the laboratory and analyzed for proximate composition according to AOAC (1995) methods and as enunciated by Suchý et al.(2002). The gross energy of each of the parts was also determined using a bomb calorimeter.

The meat samples were cooked at $170^{\circ} \mathrm{C}$ in a conventional pre-heated gas oven for 50 minutes. Cooked meat was removed from the oven, allowed to cool for 10 minutes, deboned and muscles cubed and served to a 10-member trained panel. A nine-point hedonic scoring scale was used to score the meat samples for sensory parameters. The panelists were made to score each sample for tenderness, flavour, juiciness, saltiness, colour and overall acceptability. The data obtained were subjected to a t-test (SAS, 1999 ) at $5 \%$ level of significance.

\section{RESULTSANDDISCUSSION}

The composition (in percentage) of the experimental diets shown in table I revealed the determined analyses for both broiler starter and finisher diets to be within the range recommended by NRC (1994).

The live weight gain and dressing percentage shown in table II gave higher values in Marshal MY strain ( $\mathrm{p}>0.05)$. Although, the sensory attributes determined for the breast and thigh meat of the

Table I. Composition (\%) of experimental diets. (Composición (\%) de las dietas experimentales).

\begin{tabular}{lcc}
\hline & \multicolumn{2}{c}{ Broiler diet } \\
Ingredient & starter & finisher \\
& & \\
\hline Maize & 41.50 & 47.50 \\
Soybean meal & 22.00 & 10.00 \\
Wheat offal & 13.00 & 20.00 \\
Fish meal (72\%) & 2.50 & 2.50 \\
Groundnut cake & 16.00 & 15.00 \\
Bone meal & 3.00 & 3.00 \\
Oyster shell & 1.00 & 1.00 \\
Salt & 0.25 & 0.25 \\
Methionine & 0.50 & 0.50 \\
*Vitamin/mineral premix & 0.25 & 0.25 \\
Total & 100.00 & 100.00 \\
& & \\
Determined analysis & & \\
Crude protein (\%) & 24.36 & 20.18 \\
Crude fibre (\%) & 3.58 & 3.14 \\
Metabolizable energy (MJ/kg) & 11.85 & 12.29 \\
\hline
\end{tabular}

*Premix composition: (Univit, 15 Roche) 1500 I.U, Vit. A, 1500 I.U, Vit. D, 3000 I.U, Vit. E, 3.0 g, Vit. $\mathrm{K}$, Vit. B2 $0.3 \mathrm{~g}$, Vit. B6, $8.0 \mathrm{mg}$, Vit. B12, $8.0 \mathrm{~g}$, Nicotinic acid, $3.0 \mathrm{~g}$, Ca-Pantothenate, $50 \mathrm{mg}$, Fe, $10.00 \mathrm{~g}, \mathrm{Al}, 0.2 \mathrm{~g}, \mathrm{Cu}, 3.5 \mathrm{mg}, \mathrm{Zn}, 0.15 \mathrm{mg}, \mathrm{I}, 0.02$ $\mathrm{g}, \mathrm{Co}, 0.01 \mathrm{~g}$. 


\section{COMPARISON OF MEAT COMPOSITION AND SENSORY VALUES OF BROILERS}

Table II. Effects of strains of broiler chickens on sensory values ( \pm SE) of breast and thigh meat (18 birds/treatment). (Efectos de la línea de aves sobre los valores $( \pm$ SE) sensoriales de la carne de pechuga y muslo (18 aves/tratamiento)).

\begin{tabular}{lcc}
\hline & \multicolumn{2}{c}{$\begin{array}{c}\text { Strain } \\
\text { Attribute }\end{array}$} \\
& Arbor acre Marshal MY \\
\hline Live weight gain $(\mathrm{g} / \mathrm{bird})$ & $0.84 \pm 0.04$ & $1.08 \pm 0.14$ \\
Dressing percentage & $84.36 \pm 1.25$ & $85.81 \pm 1.79$ \\
Breast & & \\
$\quad$ Tenderness & $6.09 \pm 0.24$ & $5.97 \pm 0.74$ \\
Flavour & $6.31 \pm 0.23$ & $6.13 \pm 0.32$ \\
Juiciness & $6.48 \pm 0.23$ & $6.03 \pm 0.26$ \\
Saltiness & $5.23 \pm 0.23$ & $5.30 \pm 0.12$ \\
Colour & $6.30 \pm 0.15$ & $6.37 \pm 0.19$ \\
Acceptability & $6.51 \pm 0.30$ & $6.37 \pm 0.20$ \\
Thigh & & \\
Tenderness & $7.23 \pm 0.42$ & $6.47 \pm 0.43$ \\
Flavour & $6.37 \pm 0.19$ & $6.10 \pm 0.32$ \\
Juiciness & $6.70 \pm 0.06$ & $6.30 \pm 020$ \\
Saltiness & $5.30 \pm 0.15$ & $5.37 \pm 0.37$ \\
Colour & $6.37 \pm 0.09$ & $5.97 \pm 0.34$ \\
Acceptability & $6.40 \pm 0.15$ & $5.90 \pm 0.44$ \\
\hline
\end{tabular}

two different strains showed no significant $(p>0.05)$ difference, clear variations were observed. The results showed that breast and thigh meats from Arbor acre chickens were less tough than those from Marshal MY chickens. The higher tenderness of meat from the Arbor acre chickens could be linked to the lower fibre diameter value compared to Marshal MY chickens. Furthermore, meat from the Arbor acre strains had higher scores for flavour, juiciness and acceptability. Differences in colour and texture could be attributed to fibre size and broiler great-grandparent lines. These results agree with those of Roberson et al. (2004), who reported no significant strain effect on colour density of breast meat.

The proximate compositions, fibre diameter and gross energy of breast and thigh muscles are shown in tableIII. There were significant differences between the strains on protein and dry matter compo- sitions on breast and thigh muscles as against the findings of Abeni and Bergoglio (2001). Arbor acre chickens had higher crude protein values than Marshal MY chickens for breast and thigh meat. Conversely, dry matter percentages were less in Arbor acre strains than in the Marshal MY strains. Marshal MY strain had higher $(\mathrm{p}<0.05)$ values for fat $(8.08 \%)$, dry matter $(28.73 \%)$, fibre diameter (5.24 mm) and gross energy (2.11 $\mathrm{kcal} / \mathrm{g}$ ) in the thigh muscle. It could be inferred from the results that moisture content was higher in Arbor acre meat than in Marshal MY meat for both breast and thigh. A different pattern was observed for

Table III. Proximate composition (air-dry basis), fibre diameter and gross energy of breast and thigh meat from two strains of broiler chickens (9 birds/treatment; $\pm S E$ ). (Composición proximal (base: seco al aire) diámetro de la fibra y energía bruta de la carne de la pechuga y muslo de dos líneas de broilers ( 9 aves por tratamiento; \pm SE).

\begin{tabular}{lcc}
\hline & \multicolumn{2}{c}{ Strain } \\
Parameter & Arbor acre & Marshal MY \\
\hline Breast & & \\
Fibre diameter & $5.36 \pm 0.030^{\mathrm{b}}$ & $5.54 \pm 0.015^{\mathrm{a}}$ \\
Dry matter $^{2}$ & $27.78 \pm 0.055^{\mathrm{b}}$ & $29.88 \pm 0.035^{\mathrm{a}}$ \\
Crude protein $^{2}$ & $26.60 \pm 0.101^{\mathrm{a}}$ & $25.49 \pm 0.210^{\mathrm{b}}$ \\
Fat $^{\mathrm{a}}$ & $9.72 \pm 0.021$ & $9.92 \pm 0.078$ \\
Crude fibre $^{2}$ & $0.00 \pm 0.000$ & $0.00 \pm 0.00$ \\
Ash $^{2}$ & $11.21 \pm 0.020$ & $11.73 \pm 0.620$ \\
Gross energy $^{3}$ & $2.12 \pm 0.003$ & $2.12 \pm 0.008$ \\
Thigh & & \\
Fibre diameter $^{1}$ & $3.19 \pm 0.023^{\mathrm{b}}$ & $5.24 \pm 0.006^{\mathrm{a}}$ \\
Dry matter $^{2}$ & $26.25 \pm 0.067^{\mathrm{b}}$ & $28.73 \pm 0.019^{\mathrm{a}}$ \\
Crude protein $^{2}$ & $29.92 \pm 0.101^{\mathrm{a}}$ & $28.99 \pm 0.156^{\mathrm{b}}$ \\
Fat $^{2}$ & $7.95 \pm 0.061$ & $8.08 \pm 0.075$ \\
Crude fibre $^{2}$ & $0.00 \pm 0.00$ & $0.00 \pm 0.00$ \\
Ash $^{2}$ & $13.40 \pm 0.032$ & $12.42 \pm 0.682$ \\
Gross energy $^{3}$ & $2.09 \pm 0.009^{\mathrm{b}}$ & $2.11 \pm 0.006^{\mathrm{a}}$ \\
\end{tabular}

${ }^{a b} M e a n s$ within the same row with different superscripts are significantly $(p<0.05)$ different. SE: Standard error.

${ }^{1} \mathrm{~mm} ;{ }^{2 \%} ;{ }^{3} \mathrm{kcal} / \mathrm{g}$. 
fat content since higher percentage fat values were recorded for the breast meat in both strains. This variation could be attributed to differences in genotypes of the birds used for the experiments at various points in time. The observed difference in fibre diameter may be related to difference in growth rate between the two strains. It was concluded that meat quality is a function of the interaction of genotype and other environmental factors. In addition, the meat compositions showed that Marshal MY strain had a higher significant strain

\section{REFERENCES}

Abeni, F. and Bergoglio, G. 2001. Characterization of different strains of broiler chicken by carcass measurements, chemical and physical parameters and NIRS on breast muscle. Meat Sci., 57: 133-137.

Ali, A.S.A., Harrison, A.P. and Jensen, J.F. 1999 Effect of ante-mortem stressors on peri-mortem and post-mortem biochemical changes and tenderness in broiler breast muscle. Worlds Poultry Sci. J., 55: 403-414.

AOAC. 1995. Association of Official Analytical Chemists. Official method of analysis. $16^{\text {th }}$ Ed. Washington, D.C.

Farmer, L.J., Perry, G.C., Lewis, P.D., Nute, G.R., Piggott, J.R. and Patterson, R.L.S. 1997. Responses of two genotypes of chicken to the diets and stocking densities of conventional UK and Label Rogue production systems-II. Sensory attributes. Meat Sci., 47: difference than Arbor acre strain of broiler chickens.

\section{ACKNOWLEDGEMENT}

The authors wish to express their gratitude to Poultry Management Committee of the University of Agriculture, Abeokuta for providing facilities for raising the birds. Also, Miss J.A. Adegbite (Principal Laboratory Technologist) of the Department of Animal Production and Health, University of Agriculture, Abeokuta is appreciated for assisting in laboratory analysis.

77-93.

Le Bihan-Duval, E. 2005. Genetic variability of poultry meat quality. Institut National de la Recherché Agronomique, Station de Recherché Avicoles, 37380, Nouzilly.

NRC. 1994. National Research Council. Nutrient requirement of poultry. National Academy of Science. Washington DC.

Roberson, K.D., Kalbfleisch, J.L. and Dransfield, D. 2004. Comparison of growth performance and carcass component yield of a new strain of tom turkeys to other commercial strains. International. J. Poultry Sci., 3: 791-795.

SAS. 1999. Statistical Analysis System. Version 8. SAS Institute Inc. Cary, N.C. USA.

Suchý, P., Jelínek, P., Straková, E. and Hucl, J. 2002. Chemical composition of muscles of hybrid broiler chickens during prolonged feeding. Czech J. Anim. Sci., 47: 511-518. 